\title{
CO-INOCULATION OF GROWTH PROMOTING BACTERIA AND Glomus clarum IN MICROPROPAGATED CASSAVA PLANTS ${ }^{1}$
}

\author{
ESMERALDA APARECIDA PORTO LOPES ${ }^{2}$, ALMIR DIAS ALVES DA SILVA ${ }^{3}$, ADÁLIA CAVALCANTI DO \\ ESPÍRITO SANTO MERGULHÃO ${ }^{3}$, EMMANUELLA VILA NOVA DA SILVA², ANTÔNIO DIAS SANTIAGO ${ }^{4}$, \\ MÁRCIA DO VALE BARRETO FIGUEIREDO ${ }^{3 *}$
}

\begin{abstract}
Arbuscular mycorrhizal fungi (AMF) and growth promoting bacteria in plants (PGPBs) benefit the survival and development of plantlets; such benefits are attributed to the increased absorption of nutrients, increased photosynthetic rate and tolerance to abiotic stress. The aim of this study was to evaluate if the coinoculation PGPBs and the AMF, Glomus clarum, improves the growth of micropropagated Manihot esculenta Crantz. The experiment was conducted in the greenhouse. The PGPBs used were Azospirillum amazonense (BR 11140), Herbaspirillum seropedicae (BR 11175), Gluconacetobacter diazotrophicus (BR 11284) and Streptomyces sp. (S 30) and mixtures with double inoculation (Streptomyces sp + A. amazonense, Streptomyces $s p+H$. seropedicae, Streptomyces $s p+G$. diazotrophicus, A. amazonense $+H$. seropedicae, A. amazonense + $G$. diazotrophicus, and H. seropedicae + G. diazotrophicus). Strains of PGPBs inoculated in cassava cv. "BRA Pretinha III" influenced mycorrhizal colonization and the number of glomerospores, and synergistic effects occurred between Glomus clarum and PGPBs. The crude protein content revealed the contribution of PGPBs to nitrogen nutrition in cassava where the inoculated plants assimilated $\mathrm{N}$ in equal proportion with those that received mineral nitrogen. The combined inoculation of PGPBs in the presence of Glomus clarum was significant in cassava and fostered better performance in plant growth over time, similar to all the variables studied. Co-inoculation of PGPBs and AMF can meet the $\mathrm{N}$ need of cassava, with implications for the reduced use of $\mathrm{N}$ fertilizer.
\end{abstract}

Keywords: Manihot esculenta Crantz. Micropropagation. PGPB. Synergism. Spodsol.

\section{CO-INOCULAÇÃO DE BACTÉRIAS PROMOTORAS DE CRESCIMENTO EM PLANTAS E Glomus clarum EM MANDIOCA MICROPROPAGADA}

\begin{abstract}
RESUMO - Os fungos micorrízicos arbusculares (FMA) e com as bactérias promotoras de crescimento (BPCPs) beneficiam a sobrevivência e o desenvolvimento de plântulas; tais benefícios são atribuídos ao aumento da absorção de nutrientes, aumento da taxa fotossintética, e aumento da tolerância a estresse abiótico. O objetivo deste estudo foi o de avaliar se a co-inoculação de BPCPs e do FMA, Glomus clarum, melhora o crescimento de Manihot esculenta Crantz micropropagada. As BPCPs utilizadas foram Azospirillum amazonense (BR 11140), Herbaspirillum seropedicae (BR 11175), Gluconacetobacter diazotrophicus (BR 11284) e Streptomyces sp. (S 30), isoladas e em mistura com dupla inoculação (Streptomyces sp. + A. amazonense), (Streptomyces sp. + H. seropedicae), (Streptomyces sp. + G. diazotrophicus), (A. amazonense + H. seropedicae), (A. amazonense $+G$. diazotrophicus $),(H$. seropedicae $+G$. diazotrophicus $)$. As estirpes de BPCPs inoculadas na mandioca cv. "BRA Pretinha III" influenciaram a colonização micorrízica e o número de glomerosporos. Nessas condições ocorreram efeitos sinérgicos de Glomus clarum com essas BPCPs. O teor de proteína bruta revelou a contribuição de BPCPs na nutrição nitrogenada de mandioca em que as plantas inoculadas assimilaram $\mathrm{N}$ em proporção igual àquelas que receberam nitrogênio mineral. A inoculação combinada de BPCPs na presença de Glomus clarum foi significativa na mandioca e melhorou o crescimento da planta ao longo do tempo, como em todas as variáveis estudadas. A co-inoculação de BPCPs e FMA pode atender a necessidade de $\mathrm{N}$ para mandioca, implicando redução no uso de fertilizante nitrogenado.
\end{abstract}

Palavras-chave: Manihot esculenta Crantz. Micropropagação. BPCP. Sinergismo. Espodossolo.

\footnotetext{
${ }^{*}$ Corresponding author

${ }^{1}$ Received for publication in $05 / 20 / 2017$; accepted in $07 / 30 / 2018$.

Paper the extracted from the doctoral thesis of the first author.

${ }^{2}$ Agronomy Department, Universidade Federal Rural de Pernambuco, Recife, PE, Brazil; eportolopes@yahoo.com.br - ORCID: 0000-0003 -3765-0712, manuvilanova@yahoo.com.br - ORCID: 0000-0002-0306-3512.

${ }^{3}$ Instituto Agronômico de Pernambuco, Recife, PE, Brazil; almir.dias@ipa.br - ORCID: 0000-0001-7096-4209, adalia.mergulhao@ipa.br ORCID: 0000-0003-1148-9967, marcia.figueiredo@ipa.br - ORCID: 0000-0002-0449-2810.

${ }^{4}$ Empresa Brasileira de Pesquisa Agropecuária - Tabuleiro Costeiro, Rio Largo, AL, Brazil; antonio.santiago@embrapa.br - ORCID: 00000001-6985-2402.
} 


\section{INTRODUCTION}

Cassava (Manihot esculenta Crantz) is one of the most exploited crops in world agriculture, occupying approximately 20 million hectares with a production of approximately 276 million tons of roots (FAO 2014). In Brazil in 2017, cassava production was estimated to be approximately 21 million tons (IBGE, 2017).

Traditionally, it is one of the staple foods used by man in the tropics and it is estimated that millions of people depend on cassava in Africa, Asia and Latin America, not only as an important buffer against hunger for poor people but also as a source of employment and income (OLUKUNLE, 2013). However, its average yield $\left(13 \mathrm{t} \cdot \mathrm{ha}^{-1}\right)$ is below its productive potential that, under ideal growing conditions, can reach $80 \mathrm{t} / \mathrm{ha} /$ year of roots (ELSHARKAWY, 2012); this has been attributed to several biotic and abiotic factors.

Among these factors, the quality of planting material is directly related to budding and plant vigor and, consequently, the production of roots. Cassava has a relatively long growth cycle and is propagated vegetatively; therefore, plants are exposed to many pests and diseases that can be spread over generations, contributing to a significant reduction in yield (MATTOS; SOUZA; FERREIRA FILHO, 2006).

In this regard, the technique of vegetative propagation in vitro enables, in a short time, a large number of identical plantlets and excellent sanitary conditions, allowing the establishment of large-scale plantations (RAAMAN; PATHARAJAN, 2006). However, the plantlets have less vigor and low performance when transferred from in vitro to ex vitro conditions (MELLO et al., 2002). This is due to the sterile and aseptic filling system in which the plants are produced by removing microorganisms that may favor seedling establishment (PANICKER et al., 2007). Some of these microorganisms produce or induce the production of primary and secondary metabolites that can confer several benefits to the host plants such as increased tolerance to abiotic stress (BOGINO et al., 2013), growth promotion (RODRIGUES et al., 2013) and the biological control of plant pathogens (LIU et al., 2014).

Studies have shown that microbial interactions between bacteria and arbuscular mycorrhizal fungi (AMF) have benefits that facilitate both the improvement of soil fertility (AZCÓNAGUILAR; BAREA, 2015) and also stimulate sanitation and plant nutrition (WANG et al., 2011) and promote plant growth (ARTHURSON et al., 2011). These benefits were attributed to the increase in the germination rate and AMF growth promoted by PGPBs, stimulating greater mycorrhizal colonization (JADERLUND et al., 2008), and consequently greater absorption of water and nutrients. On the other hand, exudates from the hyphae of AMF can stimulate bacterial growth and change the structure of bacterial communities (VARELA-CERVERO et al., 2016).

Knowing that the combined use of microorganisms is poorly studied in cassava seedlings, the hypothesis is that the interaction of growth promoting bacteria in plants (PGPBs) and the arbuscular mycorrhizal fungus Glomus clarum in cassava plants micropropagated in "BRA Pretinha III" cultivar can optimize growth, vigor and plant health, which will likely increase the survival rate. The aim of this study was to evaluate if the coinoculation of growth promoting bacteria in plants (PGPBs) and the AMF, Glomus clarum, improves the growth of micropropagated $M$. esculenta Crantz. Different PGPBs inoculated alone and in combination were evaluated and different biological and physiological parameters were analyzed in this study.

\section{MATERIAL AND METHODS}

\section{Experimental Design}

The experimental design was a randomized block design with a $12 \times 2$ factorial arrangement (inoculation of 4 individual strains and 6 mixtures + 2 controls: absolute (without bacteria) and without nitrogen $(\mathrm{CT})$ and control nitrogen $(\mathrm{CN})$ with and without AMF (Glomus clarum), with 3 repetitions). The PGPBs included were as follows: Azospirillum amazonense (BR 11140), Herbaspirillum seropedicae (BR 11175), Gluconacetobacter diazotrophicus (BR 11284) and Streptomyces sp. (S 30), and mixtures with double inoculation (Streptomyces $s p+A$. amazonense, Streptomyces $s p$ $+H$. seropedicae, Streptomyces $s p+G$. diazotrophicus, A. amazonense $+H$. seropedicae, $A$. amazonense $+G$. diazotrophicus, and $H$. seropedicae + G. diazotrophicus).

Multiplication and preparation of bacterial inoculants

For multiplication and preparation of inoculants were used strains Azospirillum amazonense (BR 11140), Herbaspirillum seropedicae (BR 11175) and Gluconacetobacter diazotrophicus (BR 11284) from the collection of the Centro Nacional de Pesquisa em Agrobiologia (CNPAB, RJ-Brazil) and Streptomyces sp. (S 30) from the collection of the Universidade Federal de Pernambuco (UFPE, Department of Antibiotics). To obtain the inoculant, strains were grown in Erlenmeyer flasks containing specific culture media. Strains BR 11140, BR 11175 and BR 11284 were grown in DYGS culture medium (Dextrose Yeast Glucose Sucrose) for 48 hours, while the S 30 strain was grown in ALA culture medium (arginine, and 
yeast agar) for 120 hours. All strains were kept in agitation $200 \mathrm{rpm}$ and $29^{\circ} \mathrm{C}$.

\section{Multiplication of Glomus clarum}

The isolate from AMF Glomus clarum (NICOLSON; SCHENCK, 1979) was multiplied in a greenhouse in cultivation pots with a capacity of 3.0 $\mathrm{kg}$ soil-pot ${ }^{-1}$, containing a mixture of soil (Spodosol) and vermiculite $(2: 1 \mathrm{v} / \mathrm{v})$ previously autoclaved at $120{ }^{\circ} \mathrm{C}$ and $101 \mathrm{kPa}$ for 1 hour and repeated for three consecutive days, with millet (Panicum miliaceum L.) as the host plant. After the multiplication, the inoculum produced was rated by the number of glomerospores employing tailing techniques and wet sieving (GERDEMANN; NICOLSON, 1963) and complemented by centrifugation technique and sucrose flotation (50\%) (JENKINS, 1964). The spore count was performed on grooved plates under a stereoscopic microscope (40x).

\section{Selection and disinfection of cuttings}

Cuttings of the cultivar "BRA Pretinha III", cataloged in the Germplasm Bank of Itapirema Experimental Station - IPA/Goiana/Pernambuco, were used and sterilized according to Araújo et al. (2002). The experiment was conducted in a greenhouse, and the cuttings were planted in trays for germination containing a mixture of commercial substrate + washed sand $(1: 1)$, autoclaved at $120{ }^{\circ} \mathrm{C}$ and $101 \mathrm{kPa}$ for 1 hour; $\mathrm{pH}$ was adjusted to 6.0 and maintained in the pot until sprouting.

\section{Isolation of shoots, establishment of stem apexes and multiplication of cassava plants}

Shoots were collected from 15 days after planting (DAP), decontaminated under a laminar flow chamber according to the methods described by Souza et al. (2009). The apexes were isolated and established in the MS medium (MURASHIGE; SKOOG, 1962) supplemented with thiamine-HCl (1 $\left.\mathrm{mg} \cdot \mathrm{l}^{-1}\right)$, inositol $\left(100 \mathrm{mg} \cdot \mathrm{l}^{-1}\right)$, naphthaleneacetic acid (NAA) $\left(0.02 \mathrm{mg} \cdot \mathrm{l}^{-1}\right)$, benzylaminopurine (BAP) $\left(0.04 \mathrm{mg} \cdot \mathrm{l}^{-1}\right)$, gibberellic acid (GA3) $\left(0.05 \mathrm{mg} \cdot \mathrm{l}^{-1}\right)$, sucrose $\left(20 \mathrm{~g} \cdot \cdot^{-1}\right)$ (ROCA et al., 1991), and agar ( $8 \mathrm{~g} \cdot 1$ $\left.{ }^{-1}\right)$. The multiplication was conducted when seedlings reached $10 \mathrm{~cm}$ length; these were sectioned into several micropiles and then placed in fresh MS medium with the same basic medium composition as that used in the establishment of apexes, varying only in the concentration of NAA, BAP and GA3 regulators, which all measured $0.01 \mathrm{mg} \cdot \mathrm{l}^{-1}$. In both the establishment and multiplication stages, $\mathrm{pH}$ was adjusted to 5.7 and seedlings were kept in a growth chamber under conditions of $26 \pm 1{ }^{\circ} \mathrm{C}$ temperature, artificial light (1948 lux) and a 16-hour photoperiod (SOUZA et al., 2009).

\section{Inoculation of $P G P B$ s and acclimatization}

The plantlets were individualized in vitro when presenting roots and leaves in abundance, their roots were washed with autoclaved distilled water and part of their roots were cut $(2 \mathrm{~cm})$ and then transferred to test tubes with modified MS culture medium (without hormones, with 10 times lower concentration of sucrose and nutrients and no agar) according to the methodology of Reis (2004). They were then inoculated with a bacterial suspension

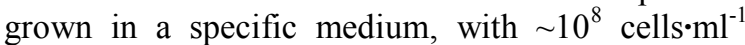
bacterial density. For treatments with individual strains, the roots were inoculated with a $2 \mathrm{ml}$ suspension, whereas for those with a double inoculation of strains, roots were inoculated with 1 $\mathrm{ml}$ of each strain. The control treatment (CT) did not receive a bacterial suspension. Seedlings were kept in a growth room at $26 \pm 1{ }^{\circ} \mathrm{C}$ under artificial light (1948 lux) and a $16 \mathrm{~h}$ photoperiod.

After 10 days, seedlings were planted in 0.51 disposable plastic cups filled with a soil autoclaved mixture of Spodosol + commercial substrate at 1:1 ratio $(\mathrm{pH} 6.0)$ and acclimatized in a greenhouse. The inoculation with AMF was determined to be $1.40 \mathrm{~g}$ of propagules, containing approximately 200 glomerospores. Each seedling was covered with a white plastic cup for maintenance of moisture, as described by Souza et al. (2009). After 20 days of planting, coverage cups were destroyed, and seedlings were fed weekly on Hoagland and Arnon solution (1950), free of $\mathrm{P}$ and $\mathrm{N}$, as reported by Jarstfer and Sylvia (1992); Silveira et al. (1998) for a period of over 34 days.

\section{Transplant to pots}

At 34 DAP, plants were transplanted in pots with a capacity of $8 \mathrm{~kg}$ of soil pot $^{-1}$ (Orthic Duric Spodosol) previously fertilized, according to the soil chemical analysis that showed the following properties in the $0-20 \mathrm{~cm}$ layer: $\mathrm{pH}_{\mathrm{H} 2 \mathrm{O}} 5.50 ; 16$ $\mathrm{mg} \cdot \mathrm{dm}^{-3} \mathrm{P} ; 0.06 \mathrm{Cmol}_{\mathrm{c}} \cdot \mathrm{dm}^{-3} \mathrm{~K} ; 1.30 \mathrm{Cmol}_{\mathrm{c}} \cdot \mathrm{dm}^{-3}$ $\mathrm{Ca}^{2+} ; 0.70 \mathrm{Cmol}_{\mathrm{c}} \cdot \mathrm{dm}^{-3} \mathrm{Mg}^{+2} ; 0.15 \mathrm{Cmol}_{\mathrm{c}} \cdot \mathrm{dm}^{-3} \mathrm{Al}$; $4.63 \mathrm{Cmol}_{\mathrm{c}} \cdot \mathrm{dm}^{-3} \mathrm{H}$; and sandy texture (SILVA, 2009). All treatments received $1.5 \mathrm{t} \cdot \mathrm{ha}^{-1} \mathrm{CaCO}_{3}, 67$ $\mathrm{kg} \mathrm{K} \cdot \mathrm{ha}^{-1}$ as $\mathrm{KCl}$, and the nitrogen control (NC) received $71 \mathrm{~kg} \mathrm{~N} \cdot \mathrm{ha}^{-1}$ as $\left(\mathrm{NH}_{4}\right)_{2} \mathrm{SO}_{4}$. Hoagland and Arnon (1950) solution, free of $\mathrm{P}$ and $\mathrm{N}$, was applied weekly according to Jarstfer and Sylvia (1992) and Silveira et al. (1998). The humidity was maintained at the pot capacity.

Harvest was carried out at 66 days after transplanting and the following variables were evaluated: plant height $(\mathrm{PH})$, root length (RL), stem diameter (SD), shoot dry matter (SDM), root dry matter (RDM), nitrogen accumulated in SDM $\left(\mathrm{N}_{\mathrm{ac}} \mathrm{SDM}\right)$ (determined by the Kjeldahl method by Silva (2009), shoot dry matter : root dry matter ratio (SDM/RDM), and $\mathrm{P}$ content in the shoot 
(WATANABE; OLSEN, 1965). The number of glomerospores was evaluated by counting, using the aforementioned techniques for root colonization (PHILLIPS; HAYMAN, 1970). The response to mycorrhizal colonization was calculated using the formula: $\mathrm{RM}=\mathrm{TDM}$ (total dry matter) and mycorrhizae - TDM without mycorrhiza / TDM with mycorrhiza $\times 100$ (PLENCHETTE; FORTIN; FURLAM, 1983) and crude protein $(\mathrm{CP}=\% \mathrm{~N}$ x $6.25)$.

\section{Statistical analysis}

Each variable studied was subjected to analysis of variance (ANOVA) using the statistical program SISVAR 5.1 Build 72 (FERREIRA, 2007) at $5 \%$ significance using the $\mathrm{F}$ test. Means were compared using the Tukey's test $(\mathrm{p}<0.05)$.

\section{RESULTS AND DISCUSSION}

A significant difference was found by the Tukey test $(\mathrm{p}<0.05)$ in the mycorrhizal colonization variable when compared with PGPBs strains. The S $30+$ BR 11140 treatment (Streptomyces sp + Azospirillum amazonense) had low colonization when compared with the double inoculation with strains BR $11140+$ BR 11284 (Azospirillum amazonense + Gluconcetaobacter diazotrophicus) and S 30 + BR 11284 (Streptomyces sp. + Gluconcetaobacter diazotrophicus), which promoted approximately $50 \%$ and $44 \%$ increase in the colonization when compared with S30 + BR 11140 . Despite the increase in mycorrhizal colonization by PGPBs, it was usually observed that they did not differ significantly $(\mathrm{p}<0.05)$ from the control $(\mathrm{CT}+$ AMF) when inoculated with Glomus clarum.

This study has shown that roots usually had high mycorrhizal colonization, and this may be related to the high degree of mycotrophism in cassava, especially in the early stages of growth, when the radicular system is undeveloped. Additionally, many other factors can also influence mycorrhizal colonization, such as soil chemical and physical properties, environmental conditions, and aspects inherent to the plant, such as health and phenology (VACHERON et al., 2013).

The percentage of mycorrhizal colonization in cassava plants from the meristem cultivation in a greenhouse has been reported to range from $62.8 \%$ to $69.8 \%$ when not inoculated with PGPBs (CORREA et al., 1992) and from $65.4 \%$ to $89.8 \%$ when co-inoculated with PGPBs (BALOTA et al., 1997). However, little stimulation of PGPBs on mycorrhizal colonization was observed when compared with $\mathrm{CT}+G$. clarum, and this may be related to the competition between bacteria and fungi for photoassimilates produced by plants (MORTIMER et al., 2008).

Regarding the number of glomerospores, significant differences were detected $(p<0.05)$ for the PGPBs inoculation (Table 1). The highest number of spores of $G$. clarum occurred in the absence of PGPBs (CT + AMF); however, the CT + AMF did not differ significantly from most PGPBs, except for the inoculation with both BR $11140+$ BR 11175 (A. amazonense + Herbaspirillum seropedicae) and BR $11284+$ BR 11175 (G. diazotrophicus + Herbaspirillum seropedicae), which showed a decrease of $851 \%$ and $267 \%$ when compared with CT + AMF, respectively.

Table 1. Mycorrhizal colonization and number of glomerospores of micropropagated plants of cassava (Manihot esculenta Crantz) cv. (BRA Pretinha III) evaluated at 100 days after planting in relation to inoculation with PGPB and Glomus clarum.

\begin{tabular}{lcc}
\hline Treatments & $\begin{array}{c}\text { Mycorrhyzal colonization } \\
(\%)\end{array}$ & $\begin{array}{c}\mathrm{N}^{0} \text { of glomerspores * } \\
50 \mathrm{~g} \cdot \mathrm{solo}^{-1}\end{array}$ \\
\hline S. sp. & $80.00 \mathrm{ab}$ & $142.33 \mathrm{abc}$ \\
A. amazonense & $76.67 \mathrm{ab}$ & $201.33 \mathrm{abc}$ \\
H. seropedicae & $77.00 \mathrm{ab}$ & $322.00 \mathrm{ab}$ \\
G. diazotrophicus & $79.33 \mathrm{ab}$ & $205.00 \mathrm{abc}$ \\
S. sp. + A. amazonense & $59.33 \mathrm{c}$ & $221.00 \mathrm{abc}$ \\
S. sp. + H. seropedicae & $68.00 \mathrm{cb}$ & $191.00 \mathrm{abc}$ \\
S. sp. + G. diazotrophicus & $85.67 \mathrm{a}$ & $245.00 \mathrm{abc}$ \\
A. amazonense + H. seropedicae & $79.67 \mathrm{ab}$ & $46.33 \mathrm{c}$ \\
A. amazonense + G. diazotrophicus & $89.33 \mathrm{a}$ & $142.00 \mathrm{abc}$ \\
G. diazotrophicus + H. seropedicae & $77.67 \mathrm{ab}$ & $120.00 \mathrm{bc}$ \\
CN & $78.67 \mathrm{ab}$ & $240.33 \mathrm{abc}$ \\
CT+AMF & $81.67 \mathrm{ab}$ & $441.00 \mathrm{a}$ \\
Means & 77.75 & 209.78 \\
\hline (\%) CV & 14.37 & 31.80 \\
\hline
\end{tabular}

Means followed by the same lower case letter in the same column did not differ by Tukey test $(\mathrm{p}<0.05)$ Azospirillum amazonense (BR 11140), Herbaspirillum seropedicae (BR 11175), Gluconacetobacter diazotrophicus (BR 11284), Streptomyces sp (S 30), nitrogen control (NC) and absolute control (CT). *For statistical analysis, the glomerospores data were transformed into $\mathrm{y}=(\mathrm{x}+0.5)^{0.5}$. Average of 3 repetitions. 
The existence of a microorganism in a particular time and place results from its evolution and the existence of favorable or unfavorable abiotic factors for its development (MEDINA; AZCÓN, 2010). Among these factors, flavonoids synthesized by plants seem to affect the germination of AMF spores and their growth (HASSAN; MATHESIUS, 2012).

During the free-living phase, the AMF may interact with specific bacterial populations and the establishment of mycorrhizae in plant roots may increase from 1.2 to 17.5 times (FREY-KLETT et al., 2007). In addition, bacterial proliferation before symbiosis can also promote the growth of fungi on its saprophytic state at the soil or root surface, causing or accelerating germination of fungal propagules in the soil (CHURCHLAND; GRAYSTON, 2014).

Regarding the number of glomerospores, PGPBs usually had no effect on the sporulation of $G$. clarum. However, the double inoculations with strains Azospirillum amazonense + Herbaspirillum seropedicae and Gluconacetobacter diazotrophicus $+H$. seropedicae promoted inhibition of the spore formation process when compared with the control (G. clarum only). Despite reports of synergistic effects between AMF and PGPBs by Ruíz-Sáncheza et al. (2011), little is known about the effect of rhizospheric microorganisms on AMF formation. However, these reports determined the densities and activities of populations in the rhizospheric microbial community where both bacterial inoculants can exert influence on mycorrhizal colonization (LAREEN; BURTON; SCHAFER, 2016), as the AMF on the soil microbial community (LÓPEZ-GARCÍA; AZCÓN-AGUILAR; BAREA, 2014). Such effects may be related to the production of compounds that inhibit or stimulate some microbial groups such as amino acids, plant hormones, vitamins and other organic compounds (REIS et al., 2010).

There was no significant difference in root length (Figure 1) for PGPBs when analyzed individually in the presence and absence of AMF. However, there was a significant interaction when the $G$. clarum was inoculated with the BR 11140 ( $A$. amazonense), BR 11284 (G. diazotrophicus) and when co-inoculated with S30 + BR 11284 (Streptomyces sp. + G. diazotrophicus) and $\mathrm{S} 30+$ BR 11175 (Streptomyces sp. + Herbaspirillum seropedicae); these treatments stimulated root growth by $93 \%, 48 \%$ and $46 \%$, respectively, over those plants not inoculated.

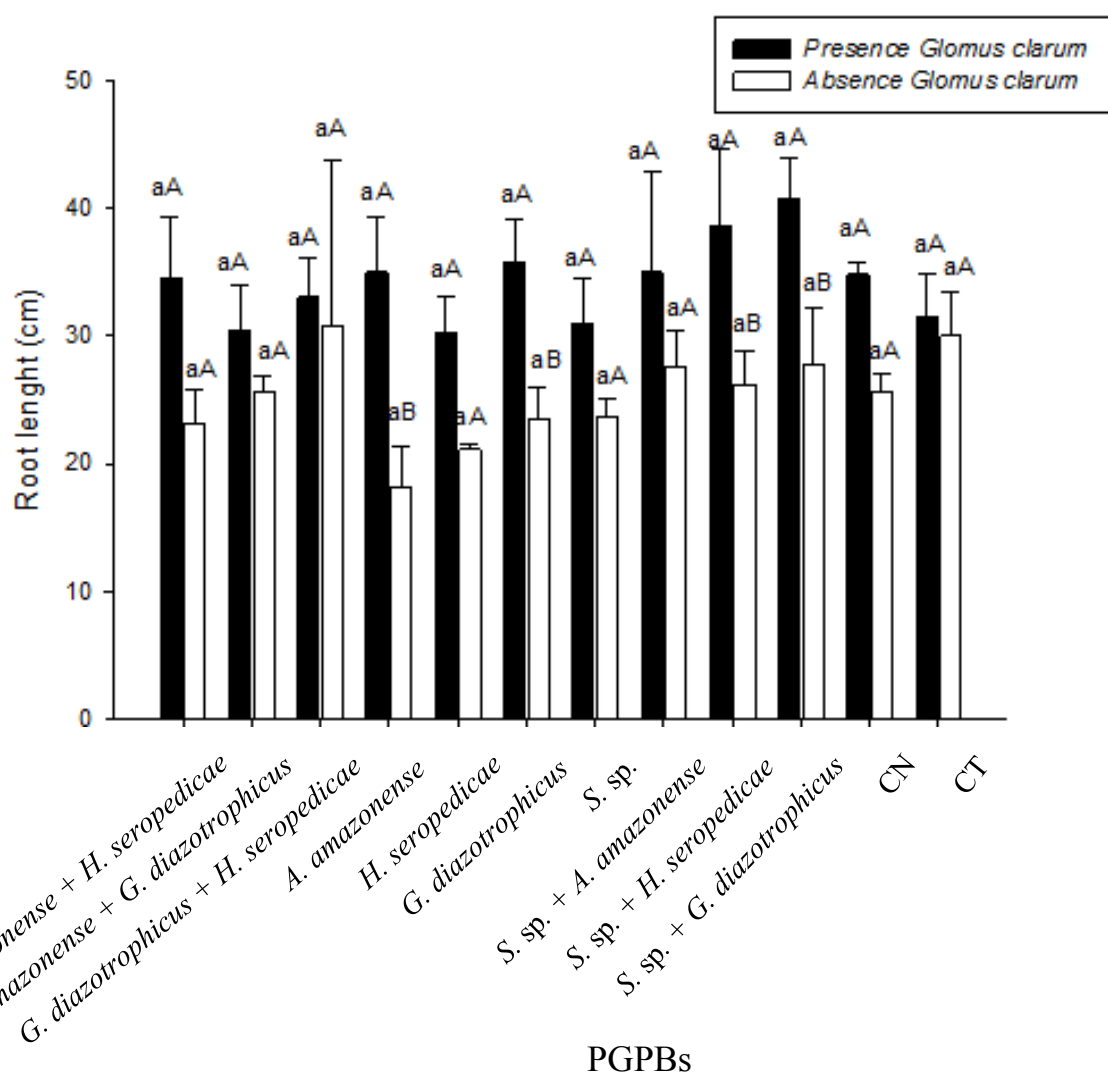

Figure 1. Root length of micropropagated plants of cassava (Manihot esculenta Crantz) cv. (BRA Pretinha III) evaluated at 100 days after planting in relation to inoculation of PGPBs and Glomus clarum in the greenhouse. Equal lowercase letters between treatments (PGPBs) and equal capital letters between presence and absence of Glomus clarum did not differ by Tukey test $(\mathrm{p}<0.05)$. Azospirillum amazonense (BR 11140), Herbaspirillum seropedicae (BR 11175), Gluconacetobacter diazotrophicus (BR 11284), Streptomyces sp (S 30), nitrogen control (CN), and absolute control (CT). Average of 3 repetitions. $\% \mathrm{CV}=24.96$.

Rev. Caatinga, Mossoró, v. 32, n. 1, p. 152 - 166, jan. - mar., 2019 
As for the promotion of plant growth, root morphology effects, such as an increase in length, the number of branches or even root hairs, have already been reported in plants colonized by PGPBs (ROESCH et al., 2005), which are generally associated with the production of phytohormones. However, in this study, exudates released by the roots, which are extremely diverse, probably promoted a greater plant-fungus-bacterium synergism in the double inoculations Streptomyces $s p .+G$. diazotrophicus and Streptomyces sp. $+H$. seropedicae, favoring a larger increase in the roots. Such responses can vary considerably in quantity and quality, depending on numerous factors, such as plant species, fungus species, bacterial strains, age and vigor of the plants, soil type and environmental factors including light, temperature and humidity (MIRANDA, 2008). It is suggested, therefore, that the combinations of microorganisms described above, inoculated in cassava at its early growth promote further growth in roots, greater extraction of nutrients from deeper environments, and a higher water uptake that optimize its production potential.

Regarding the stem diameter, there was no significant interaction between PGPBs and AMF when assessed at 49 and 100 days after planting (DAP); however, it was significant at 65 (Table 2) and 84 DAP (Table 3). The greatest stem thickness was found when the plant was inoculated with BR 11140 (A. amazonense) (65 DAP) and after double inoculation with $\mathrm{S} 30+\mathrm{BR} 11140$ (Streptomyces $s p$ + A. amazonense) (84 DAP), with increases of $40 \%$ and $33.6 \%$, respectively, when compared with the nitrogen control (CN). Regression equations (Figure 2) showed that stem diameter increased linearly both in the presence $\left(\mathrm{R}^{2}=0.95\right)$ and absence $\left(\mathrm{R}^{2}=0.99\right)$ of AMF; however, when the plant was inoculated with $G$. clarum, the stem thickness at 51 days increased by $3.25 \mathrm{~mm}$, whereas it only increased by $0.58 \mathrm{~mm}$ in the absence of the fungus.

Table 2. Stem diameter of micropropagated plants of cassava (Manihot esculenta Crantz) cv. (BRA Pretinha III) evaluated in times 49 and 65 days after planting (DAP) in relation to inoculation of PGPBs and Glomus clarum in greenhouse.

\begin{tabular}{|c|c|c|c|c|}
\hline \multirow{3}{*}{ Treatments } & \multicolumn{4}{|c|}{$\begin{array}{c}\text { Stem diameter } \\
\mathrm{mm}\end{array}$} \\
\hline & \multicolumn{2}{|c|}{49} & \multicolumn{2}{|c|}{65} \\
\hline & with AMF & non AMF & with AMF & non AMF \\
\hline S. sp. & $2.41 \mathrm{aA}$ & $1.57 \mathrm{aB}$ & $4.02 \mathrm{abA}$ & $1.82 \mathrm{aB}$ \\
\hline A. amazonense & 2.89 aA & $1.78 \mathrm{aB}$ & $4.63 \mathrm{aA}$ & $1.94 \mathrm{aB}$ \\
\hline H. seropedicae & $2.70 \mathrm{aA}$ & $1.48 \mathrm{aB}$ & $4.44 \mathrm{abA}$ & $1.62 \mathrm{aB}$ \\
\hline G. diazotrophicus & $2.80 \mathrm{aA}$ & $1.72 \mathrm{aB}$ & $4.52 \mathrm{abA}$ & $1.77 \mathrm{aB}$ \\
\hline S. sp. + A. amazonense & $2.50 \mathrm{aA}$ & $1.71 \mathrm{aB}$ & $4.36 \mathrm{abA}$ & $2.06 \mathrm{aB}$ \\
\hline S. sp. + H. seropedicae & $2.17 \mathrm{aA}$ & $1.67 \mathrm{aB}$ & $3.85 \mathrm{abA}$ & $2.15 \mathrm{aB}$ \\
\hline S. sp. + G. diazotrophicus & $2.49 \mathrm{aA}$ & $1.57 \mathrm{aB}$ & $3.65 \mathrm{abA}$ & $1.77 \mathrm{aB}$ \\
\hline A. amazonense $+H$. seropedicae & $2.49 \mathrm{aA}$ & $1.57 \mathrm{aB}$ & 4.35 abA & $1.72 \mathrm{aB}$ \\
\hline A. amazonense $+G$. diazotrophicus & $2.19 \mathrm{aA}$ & $1.98 \mathrm{aB}$ & $3.84 \mathrm{abA}$ & $1.92 \mathrm{aB}$ \\
\hline G. diazotrophicus + H. seropedicae & $2.88 \mathrm{aA}$ & $1.95 \mathrm{aB}$ & $4.53 \mathrm{abA}$ & $2.11 \mathrm{aB}$ \\
\hline $\mathrm{CN}$ & $1.98 \mathrm{aA}$ & $1.93 \mathrm{aB}$ & $3.47 \mathrm{bA}$ & $2.24 \mathrm{aB}$ \\
\hline CT & $2.28 \mathrm{aA}$ & $1.83 \mathrm{aB}$ & $3.84 \mathrm{abA}$ & $2.15 \mathrm{aB}$ \\
\hline Means & 2.48 & 1.72 & 4.12 & 1.92 \\
\hline$\% \mathrm{CV}$ & \multicolumn{2}{|c|}{19.44} & \multicolumn{2}{|c|}{13.64} \\
\hline
\end{tabular}

Means followed by the same lowercase letter between treatments within the same column and capital letter between the AMF within the same row for each parameter did not differ by Tukey test $(\mathrm{p}<0.05)$. Azospirillum amazonense (BR 11140), Herbaspirillum seropedicae (BR 11175), Gluconacetobacter diazotrophicus (BR 11284), Streptomyces sp (S 30), nitrogen control (NC) and absolute control (AC). Average of 3 repetitions. 
Table 3. Stem diameter of micropropagated plants of cassava (Manihot esculenta Crantz) cv. (BRA Pretinha III) evaluated in times 84 and 100 days after planting (DAP) in relation to inoculation of PGPBs and Glomus clarum in greenhouse.

\begin{tabular}{|c|c|c|c|c|}
\hline \multirow{3}{*}{ Treatments } & \multicolumn{4}{|c|}{$\begin{array}{c}\text { Stem diameter } \\
\mathrm{mm} \\
\end{array}$} \\
\hline & \multicolumn{2}{|c|}{84} & \multicolumn{2}{|c|}{100} \\
\hline & with AMF & non AMF & with AMF & non AMF \\
\hline S. sp. & $5.26 \mathrm{abA}$ & $2.08 \mathrm{aB}$ & $5.93 \quad \mathrm{aA}$ & $2.11 \quad \mathrm{aB}$ \\
\hline A. amazonense & $5.50 \mathrm{abA}$ & $1.99 \mathrm{aB}$ & 6.40 aA & $2.23 \mathrm{aB}$ \\
\hline H. seropedicae & $5.49 \mathrm{abA}$ & $1.90 \mathrm{aB}$ & 5.94 aA & $2.00 \mathrm{aB}$ \\
\hline G. diazotrophicus & $5.51 \mathrm{abA}$ & $1.90 \mathrm{aB}$ & 5.74 aA & $2.27 \mathrm{aB}$ \\
\hline S. sp. + A. amazonense & $6.03 \mathrm{aA}$ & $2.11 \mathrm{aB}$ & 5.95 aA & $2.17 \mathrm{aB}$ \\
\hline S. sp. + H. seropedicae & $4.80 \mathrm{abA}$ & $2.29 \mathrm{aB}$ & 5.58 aA & $2.57 \mathrm{aB}$ \\
\hline S. sp. + G. diazotrophicus & $5.17 \mathrm{abA}$ & $1.85 \mathrm{aB}$ & 5.76 aA & $1.98 \mathrm{aB}$ \\
\hline A. amazonense + H. seropedicae & $5.14 \mathrm{abA}$ & $2.12 \mathrm{aB}$ & 5.58 aA & $2.14 \mathrm{aB}$ \\
\hline A. amazonense + G. diazotrophicus & $4.71 \mathrm{abA}$ & $2.15 \mathrm{aB}$ & 5.79 aA & $2.67 \mathrm{aB}$ \\
\hline G. diazotrophicus $+H$. seropedicae & $5.53 \mathrm{abA}$ & $2.40 \mathrm{aB}$ & 5.78 aA & $2.55 \mathrm{aB}$ \\
\hline $\mathrm{CN}$ & $4.31 \mathrm{bA}$ & $2.39 \mathrm{aB}$ & $5.25 \mathrm{aA}$ & $2.54 \mathrm{aB}$ \\
\hline CT & $4.92 \mathrm{abA}$ & $2.42 \mathrm{aB}$ & 5.67 aA & $2.21 \mathrm{aB}$ \\
\hline Means & 5.19 & 2.11 & 5.76 & 2.31 \\
\hline$\% \mathrm{CV}$ & \multicolumn{2}{|c|}{13.33} & \multicolumn{2}{|c|}{13.00} \\
\hline
\end{tabular}

Means followed by the same lowercase letter between treatments within the same column and capital letter between the AMF within the same row for each parameter did not differ by Tukey test $(\mathrm{p}<0.05)$. Azospirillum amazonense (BR 11140), Herbaspirillum seropedicae (BR 11175), Gluconacetobacter diazotrophicus (BR 11284), Streptomyces sp (S 30), nitrogen control (NC) and absolute control (AC). Average of 3 repetitions.

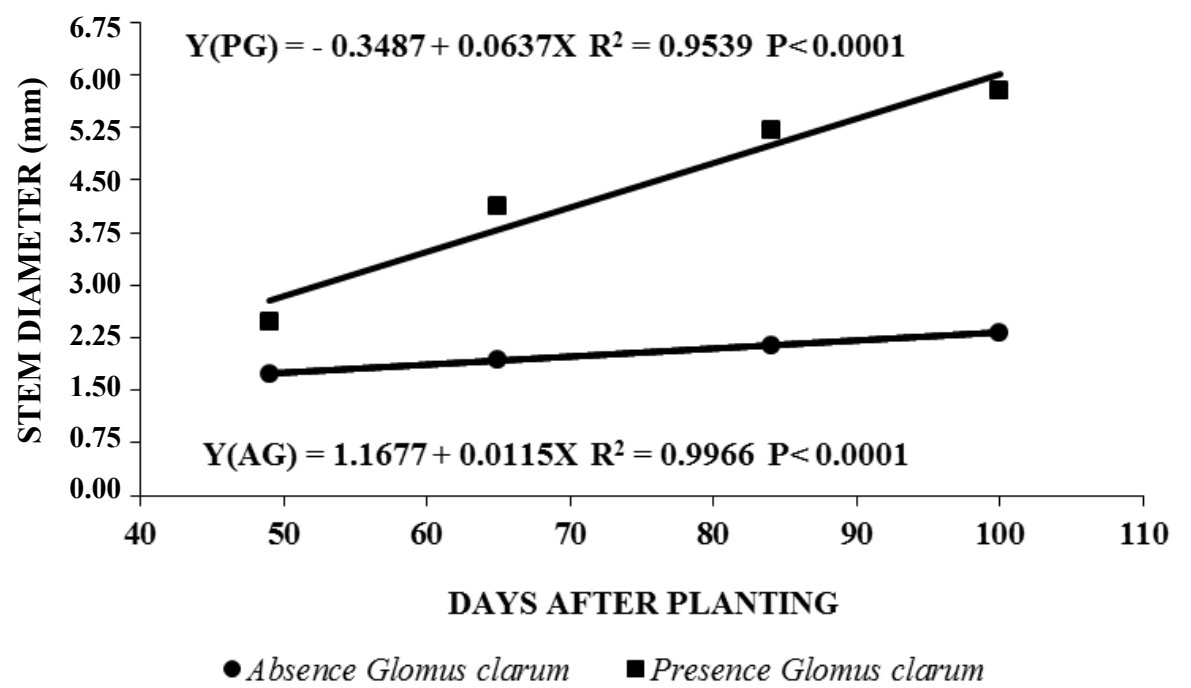

Figure 2. Stem diameter of micropropagated plants of cassava depending on the presence (AP) or absence (AG) of Glomus clarum at 49, 65, 84 and 100 days after planting in the greenhouse.

There was no interaction between PGPBs and AMF for plant height during the evaluated timeframes, 49 and 65 DAP (Table 4), 84 and 100 DAP (Table 5), but the plant height increased linearly both in the presence $\left(\mathrm{R}^{2}=0.99\right)$ and in the absence of the fungus $\left(\mathrm{R}^{2}=0.99\right)$. Greater benefits were obtained when inoculated with G. clarum, considering that plants grew $16.23 \mathrm{~cm}$ in 51 days, whereas in the absence of the fungus plants only grew $3.25 \mathrm{~cm}$ (Figure 3).

In the root dry matter accumulation (RDM) and shoot dry matter (SDM), the PGPBs, when coinoculated with $G$. clarum or in its absence, did not differ significantly using Tukey's test $(\mathrm{p}<0.05)$, but 
all the plants accumulated more RDM and SDM when in the presence of mycorrhizal fungi $(p<0.05)$. In isolated inoculation of AMF (CT), there were increases of $1.104 \%$ in the root and $1.273 \%$ in the shoot. Despite not showing a different effect depending on AMF and PGPBs, cassava plants inoculated with $H$. seropedicae (BR 11175) showed increases of $3.340 \%$ in shoots and $3.700 \%$ in roots (Table 6). It was found that the cultivar "BRA Pretinha III" was highly responsive to AMF, considering its $92 \%$ response to mycorrhizal colonization (CM). That is, the possibility of this group growing without $G$. clarum and under these soil fertility conditions was $8 \%$.

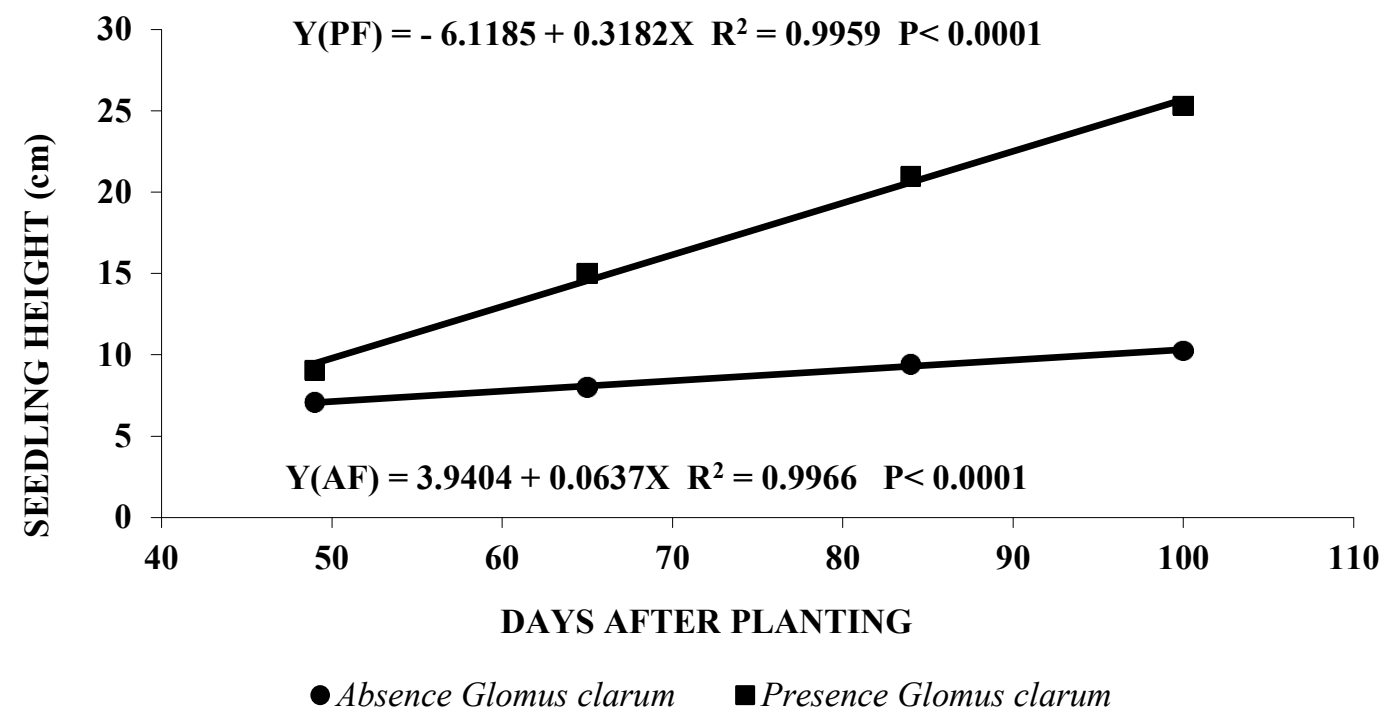

Figure 3. Height of micropropagated plants of cassava depending on the presence or absence of Glomus clarum at 49, 65, 84 and 100 days after in greenhouse. PF (presence fungi) AF (absence fungi).

Table 4. Height of micropropagated cassava plants (Manihot esculenta Crantz) cv. (BRA Pretinha III) evaluated at times 49 and 65 days after planting (DAP) in relation to inoculation of PGPBs and Glomus clarum in greenhouse.

\begin{tabular}{|c|c|c|c|c|}
\hline \multirow{3}{*}{ Treatments } & \multicolumn{4}{|c|}{$\begin{array}{l}\text { Seedling height } \\
\mathrm{cm}\end{array}$} \\
\hline & \multicolumn{3}{|c|}{ DAP } & 65 \\
\hline & with AMF & Non AMF & with AMF & Non AMF \\
\hline S. sp. & $9.33 \mathrm{aA}$ & $7.00 \mathrm{aB}$ & $18.67 \mathrm{aA}$ & $8.00 \mathrm{aB}$ \\
\hline A. amazonense & $11.67 \mathrm{aA}$ & $6.00 \mathrm{aB}$ & $15.83 \mathrm{aA}$ & $6.83 \mathrm{aB}$ \\
\hline H. seropedicae & $9.67 \mathrm{aA}$ & $6.50 \mathrm{aB}$ & $16.17 \mathrm{aA}$ & $7.33 \mathrm{aB}$ \\
\hline G. diazotrophicus & $10.67 \mathrm{aA}$ & $7.17 \mathrm{aB}$ & $15.83 \mathrm{aA}$ & $7.33 \mathrm{aB}$ \\
\hline$S$. sp. $+A$ amazonense & $8.83 \mathrm{aA}$ & $7.67 \mathrm{aB}$ & $13.33 \mathrm{aA}$ & $9.83 \mathrm{aB}$ \\
\hline S. sp. $+H$. seropedicae & $7.33 \mathrm{aA}$ & $7.83 \mathrm{aB}$ & $15.00 \mathrm{aA}$ & $8.17 \mathrm{aB}$ \\
\hline S. sp. + G. diazotrophicus & $8.17 \mathrm{aA}$ & $7.33 \mathrm{aB}$ & $13.00 \mathrm{aA}$ & $8.50 \mathrm{aB}$ \\
\hline A. amazonense $+H$. seropedicae & $9.33 \mathrm{aA}$ & $5.67 \mathrm{aB}$ & $14.67 \mathrm{aA}$ & $7.17 \mathrm{aB}$ \\
\hline A. amazonense $+G$. diazotrophicus & $8.00 \mathrm{aA}$ & $8.33 \mathrm{aB}$ & $11.83 \mathrm{aA}$ & $8.83 \mathrm{aB}$ \\
\hline G. diazotrophicus $+H$. seropedicae & $8.67 \mathrm{aA}$ & $7.00 \mathrm{aB}$ & $13.50 \mathrm{aA}$ & $8.33 \mathrm{aB}$ \\
\hline $\mathrm{CN}$ & $8.50 \mathrm{aA}$ & $6.50 \mathrm{aB}$ & $15.67 \mathrm{aA}$ & $7.67 \mathrm{aB}$ \\
\hline CT & $8.67 \mathrm{aA}$ & $7.83 \mathrm{aB}$ & $16.33 \mathrm{aA}$ & $8.17 \mathrm{aB}$ \\
\hline Means & 9.07 & 7.07 & 14.99 & 8.01 \\
\hline$\% \mathrm{CV}$ & \multicolumn{2}{|c|}{27.98} & \multicolumn{2}{|c|}{26.63} \\
\hline
\end{tabular}

Means followed by the same lowercase letter between treatments within the same column and capital letter between the AMF within the same row for each parameter did not differ by Tukey test $(\mathrm{p}<0.05)$. Azospirillum amazonense (BR 11140), Herbaspirillum seropedicae (BR 11175), Gluconacetobacter diazotrophicus (BR 11284), Streptomyces sp (S 30), nitrogen control (CT) and absolute control (CN). Average of 3 repetitions. 
Synergistic responses for the thickness of the stem diameter (SD), plant height $(\mathrm{PH})$, shoot dry matter accumulation (SDM) and root dry matter (RDM) between G. clarum and PGPBs were not observed. The results were much higher for biomass (SDM and RDM) than those found by Balota et al. (1997), who observed increases of $555 \%$ and $1,979 \%$ on SDM and RDM, respectively, when cassava plants micropropagated at 95 days after planting and inoculated only with $G$. clarum were evaluated. However, the reasons for this variability are unclear and a more mechanistic approach is required to study this relationship with micropropagated cassava plants.

Table 5. Height of micropropagated cassava plants (Manihot esculenta Crantz) cv. (BRA Pretinha III) evaluated at times 84 and 100 days after planting (DAP) in relation to inoculation of PGPBs and Glomus clarum in greenhouse.

\begin{tabular}{|c|c|c|c|c|}
\hline \multirow{3}{*}{ Treatments } & \multicolumn{4}{|c|}{$\begin{array}{l}\text { Seedling height } \\
\mathrm{cm}\end{array}$} \\
\hline & \multicolumn{2}{|c|}{84} & \multicolumn{2}{|c|}{100} \\
\hline & with AMF & Non AMF & with AMF & Non AMF \\
\hline S. sp. & $25.17 \mathrm{aA}$ & $9.33 \quad \mathrm{aB}$ & 30.83 aA & $10.50 \quad \mathrm{aB}$ \\
\hline A. amazonense & $21.50 \mathrm{aA}$ & $8.00 \mathrm{aB}$ & $25.00 \mathrm{aA}$ & $8.67 \mathrm{aB}$ \\
\hline H. seropedicae & $23.17 \mathrm{aA}$ & 8.17 & $26.50 \mathrm{aA}$ & $8.33 \mathrm{aB}$ \\
\hline G. diazotrophicus & $22.67 \mathrm{aA}$ & 8.50 & $27.83 \mathrm{aA}$ & $9.00 \mathrm{aB}$ \\
\hline S. sp. $+A$ amazonense & $17.83 \mathrm{aA}$ & $10.83 \mathrm{aB}$ & $20.67 \mathrm{aA}$ & $12.50 \mathrm{aB}$ \\
\hline S. sp. + H. seropedicae & $20.00 \mathrm{aA}$ & $10.67 \mathrm{aB}$ & $24.00 \mathrm{aA}$ & $11.50 \mathrm{aB}$ \\
\hline$S$. sp. + G. diazotrophicus & $19.17 \mathrm{aA}$ & $9.83 \mathrm{aB}$ & $23.33 \mathrm{aA}$ & $10.17 \mathrm{aB}$ \\
\hline A. amazonense $+H$. seropedicae & $19.17 \mathrm{aA}$ & $8.83 \mathrm{aB}$ & $23.00 \mathrm{aA}$ & $10.33 \mathrm{aB}$ \\
\hline A. amazonense $+G$. diazotrophicus & $16.67 \mathrm{aA}$ & $10.17 \mathrm{aB}$ & $19.83 \mathrm{aA}$ & $11.00 \mathrm{aB}$ \\
\hline G. diazotrophicus $+H$. seropedicae & $19.83 \mathrm{aA}$ & $10.17 \mathrm{aB}$ & $24.33 \mathrm{aA}$ & $11.17 \mathrm{aB}$ \\
\hline $\mathrm{CN}$ & $23.50 \mathrm{aA}$ & $8.50 \mathrm{aB}$ & $29.33 \mathrm{aA}$ & $9.50 \mathrm{aB}$ \\
\hline $\mathrm{CT}$ & $23.00 \mathrm{aA}$ & $9.83 \mathrm{aB}$ & $29.17 \mathrm{aA}$ & $10.33 \mathrm{aB}$ \\
\hline Means & 20.97 & 9.40 & 25.32 & 10.25 \\
\hline$\% \mathrm{CV}$ & \multicolumn{2}{|c|}{30.48} & \multicolumn{2}{|c|}{32.74} \\
\hline
\end{tabular}

Means followed by the same lowercase letter between treatments within the same column and capital letter between the AMF within the same row for each parameter did not differ by Tukey test $(\mathrm{p}<0.05)$. Azospirillum amazonense (BR 11140), Herbaspirillum seropedicae (BR 11175), Gluconacetobacter diazotrophicus (BR 11284), Streptomyces sp (S $30)$, nitrogen control $(\mathrm{CT})$ and absolute control $(\mathrm{CN})$. Average of 3 repetitions.

The lack of synergistic responses between PGPBs and AMF was also observed by Lima et al. (2011) in which strains of Stenotrophomonas maltophilia and Azospirillum sp. combined with $G$. clarum and Gigaspora margarita did not promote stimulatory or suppressive effects on the growth of papaya seedlings; however, inoculation with AMF increased growth significantly.

The results clearly demonstrate the symbiotic effectiveness of $G$. clarum under the studied conditions, whereas plants were greatly reduced when grown on sterilized soil without its nutritional benefits. Such benefits are the result of complex and dynamic interactions between roots and mycelium modulated by the environment, which allows the expansion of nutrient absorption capacity on the part of autotrophic symbionts and hence their interspecific competitiveness and productivity (MOREIRA et al., 2010).

The effect of AMF on plant growth is especially significant with respect to the low mobility of nutrients in the soil; these nutrients practically do not move through mass flow but reach the roots by means of diffusion mechanisms (BALEMI; NEGISHO, 2012) and include the macronutrient phosphorus $(\mathrm{P})$ and micronutrients zinc and copper (CARDOSO et al., 2010), as well as the occurrence of competition for $\mathrm{N}$ between symbionts (HODGE; STORER, 2015). 
E. A. P. LOPES et al.

Table 6. Root dry matter (RDM) and shoot dry matter (SDM) of micropropagated cassava plants (Manihot esculenta Crantz) cv. (BRA Pretinha III) evaluated at 100 days after planting in relation to inoculation of PGPBs and Glomus clarum.

\begin{tabular}{|c|c|c|c|c|}
\hline \multirow{3}{*}{ Treatments } & \multicolumn{3}{|c|}{ RDM } & SDM \\
\hline & \multicolumn{4}{|c|}{$\mathrm{g} \cdot$ plant $^{-1}$} \\
\hline & with AMF & non $\mathrm{AMF}$ & With AMF & non AMF \\
\hline S. sp. & $2.06 \mathrm{aA}$ & $0.15 \mathrm{aB}$ & 5.57 & $0.24 \quad \mathrm{aB}$ \\
\hline A. amazonense & $2.90 \mathrm{aA}$ & $0.12 \mathrm{aB}$ & 5.29 & 0.22 \\
\hline H. seropedicae & $3.04 \mathrm{aA}$ & $0.08 \mathrm{aB}$ & 5.16 & 0.15 \\
\hline G. diazotrophicus & $3.22 \mathrm{aA}$ & 0.13 & 5.06 & 0.22 \\
\hline S. sp. $+A$. amazonense & $3.34 \mathrm{aA}$ & $0.23 \mathrm{aB}$ & 4.37 & 0.34 \\
\hline$S$. sp. $+H$. seropedicae & $3.17 \mathrm{aA}$ & 0.22 & 4.34 & 0.37 \\
\hline S. sp. + G. diazotrophicus & $2.84 \mathrm{aA}$ & 0.16 & 4.76 & 0.28 \\
\hline A. amazonense $+H$. seropedicae & $3.15 \mathrm{aA}$ & 0.15 & 4.83 & 0.27 \\
\hline A. amazonense $+G$. diazotrophicus & $2.09 \mathrm{aA}$ & 0.20 & 5.22 & 0.29 \\
\hline G. diazotrophicus $+H$. seropedicae & $2.43 \mathrm{aA}$ & 0.30 & 4.93 & 0.43 \\
\hline $\mathrm{CN}$ & $2.31 \mathrm{aA}$ & 0.22 & 4.04 & 0.33 \\
\hline CT & $2.53 \mathrm{aA}$ & $0.21 \mathrm{aB}$ & $5.22 \quad \mathrm{aA}$ & $0.38 \mathrm{aB}$ \\
\hline Means & 2.76 & 0.19 & 4.89 & 0.29 \\
\hline$\% \mathrm{CV}$ & \multicolumn{2}{|c|}{37.63} & \multicolumn{2}{|c|}{21.09} \\
\hline
\end{tabular}

Means followed by the same lowercase letter between treatments within the same column and capital letter between the AMF within the same row for each parameter did not differ by Tukey test $(\mathrm{p}<0.05)$. Azospirillum amazonense (BR 11140), Herbaspirillum seropedicae (BR 11175), Gluconacetobacter diazotrophicus (BR 11284), Streptomyces sp (S $30)$, nitrogen control $(\mathrm{CN})$ and absolute control (CT). Average of 3 repetitions.

There were no significant differences in the nitrogen accumulated in the shoot dry matter $\left(\mathrm{N}_{\mathrm{ac}} \mathrm{SDM}\right)$ and root dry matter $\left(\mathrm{N}_{\mathrm{ac}} \mathrm{RDM}\right)$ in cv. "BRA Pretinha III" (Table 7) when PGPBs were coinoculated or not with $G$. clarum $(\mathrm{p}<0.05)$. However, all treatments with the AMF for both variables were higher than those without fungi $(\mathrm{p}<0.05)$, showing increases of approximately $1,605 \%$ and $892 \%$ in the accumulation of nitrogen $(\mathrm{N})$ in both the SDM and RDM, respectively, when compared with the control (without $G$. clarum). Although there has been no difference in these variables, the interaction with $G$. clarum promoted $\mathrm{N}$ accumulation by approximately $3.025 \%$ and $2.267 \%$ for SDM and RDM, respectively, when co-inoculated with BR 11175 ( $H$. seropedicae).

Table 7. Nitrogen accumulated in the shoot dry matter $\left(\mathrm{N}_{\mathrm{ac}} \mathrm{SDM}\right)$ and nitrogen accumulated in the root dry matter $\left(\mathrm{N}_{\mathrm{ac}} \mathrm{RDM}\right.$ of micropropagated cassava plants (Manihot esculenta Crantz) cv. (BRA Pretinha III) evaluated at 100 days after planting in relation to inoculation of PGPBs and Glomus clarum.

\begin{tabular}{|c|c|c|c|c|}
\hline \multirow{3}{*}{ Treatments } & \multicolumn{3}{|c|}{$\mathrm{N}_{\mathrm{ac}} \mathrm{SDM}$} & \multirow{2}{*}{$\mathrm{V}_{\mathrm{ac}} \mathrm{RDM}$} \\
\hline & \multicolumn{3}{|c|}{$\mathrm{mg} \mathrm{N} \cdot \mathrm{g}^{-1} \mathrm{SDM}$} & \\
\hline & with AMF & non AMF & with AMF & non AMF \\
\hline S. sp. & 217.58 aA & $9.97 \mathrm{aB}$ & 51.76 aA & $5.43 \mathrm{aB}$ \\
\hline A. amazonense & $194.81 \mathrm{aA}$ & $8.34 \mathrm{aB}$ & $57.52 \mathrm{aA}$ & $3.98 \mathrm{aB}$ \\
\hline H. seropedicae & $202.86 \mathrm{aA}$ & $6.49 \mathrm{aB}$ & $59.43 \mathrm{aA}$ & $2.51 \mathrm{aB}$ \\
\hline G. diazotrophicus & 200.99 aA & $10.69 \mathrm{aB}$ & $73.91 \mathrm{aA}$ & $4.38 \mathrm{aB}$ \\
\hline S. sp. + A. amazonense & $160.87 \mathrm{aA}$ & $13.69 \mathrm{aB}$ & $60.74 \mathrm{aA}$ & $7.39 \mathrm{aB}$ \\
\hline S. sp. + H. seropedicae & $189.22 \mathrm{aA}$ & $14.37 \mathrm{aB}$ & $61.09 \mathrm{aA}$ & $7.99 \mathrm{aB}$ \\
\hline$S$. sp. + G. diazotrophicus & $205.47 \mathrm{aA}$ & $8.81 \mathrm{aB}$ & 73.89 aA & $5.32 \mathrm{aB}$ \\
\hline A. amazonense $+H$. seropedicae & $196.73 \mathrm{aA}$ & $10.06 \mathrm{aB}$ & $66.90 \mathrm{aA}$ & $4.91 \mathrm{aB}$ \\
\hline A. amazonense + G. diazotrophicus & $175.62 \mathrm{aA}$ & $10.61 \mathrm{aB}$ & $50.34 \mathrm{aA}$ & $7.13 \mathrm{aB}$ \\
\hline G. diazotrophicus $+H$. seropedicae & $189.59 \mathrm{aA}$ & $15.66 \mathrm{aB}$ & $48.70 \mathrm{aA}$ & $10.38 \mathrm{aB}$ \\
\hline $\mathrm{CN}$ & $167.86 \mathrm{aA}$ & $14.65 \mathrm{aB}$ & 65.86 aA & $6.84 \mathrm{aB}$ \\
\hline $\mathrm{CT}$ & $219.36 \mathrm{aA}$ & $12.74 \mathrm{aB}$ & $59.57 \mathrm{aA}$ & $7.24 \mathrm{aB}$ \\
\hline Means & 193.41 & 11.34 & 60.81 & 6.13 \\
\hline$\% \mathrm{CV}$ & \multicolumn{2}{|c|}{20.17} & \multicolumn{2}{|c|}{32.00} \\
\hline
\end{tabular}

Means followed by the same lowercase letter between treatments within the same column and capital letter between the AMF within the same row for each parameter did not differ by Tukey test $(\mathrm{p}<0.05)$. Azospirillum amazonense (BR 11140), Herbaspirillum seropedicae (BR 11175), Gluconacetobacter diazotrophicus (BR 11284), Streptomyces $s p(\mathrm{~S} 30)$, nitrogen control $(\mathrm{CN})$ and absolute control $(\mathrm{CT})$. Average of 3 repetitions. 
In this study, despite not having observed synergistic responses between G. clarum and PGPBs in the accumulation of nitrogen $(\mathrm{N})$ in the shoot dry matter $\left(\mathrm{N}_{\mathrm{ac}} \mathrm{SDM}\right)$ and root dry matter $\left(\mathrm{N}_{\mathrm{ac}} \mathrm{RDM}\right)$, the presence of $G$. clarum released more nitrogen to plants when compared with those that were not inoculated, which may have been attributed to increased absorption surface, the exploited soil volume, and the type of fertilizer used (ammonium sulfate), which is less mobile than nitrate and more likely to be absorbed and translocated in mycorrhizal plants (CUENCA; AZCÓN, 1994).

This result is promising, and it would be highly recommended to producers. Several studies show that Glomus increases the N content in plants. Balota et al. (1997) demonstrated that treatment with G. clarum favored a higher nitrogen accumulation in micropropagated cassava plants than those inoculated with the PGPBs and the control (without AMF), confirming the results of this work. Sala, Freitas and Silveira (2007) obtained higher growth, accumulation and utilization of $\mathrm{N}$ and $\mathrm{P}$ by wheat plants when inoculated with Glomus.

PGPBs were significantly different for crude protein (CP) (Table 8) in the absence of G. clarum. BR 11175 (H. seropedicae) favored increases of $48 \%$ and $43.7 \%$ in the cassava shoot crude protein content when compared with the double inoculation $\mathrm{S} 30+\mathrm{BR} 11284$ (Streptomyces $s p+$ Gluconacetobacter diazotrophicus) and CT (absolute control). Furthermore, this strain increased the CP content by $20.7 \%(p<0.05)$ when compared with the same co-inoculated treatment containing AMF. It can also be seen that in plants free of inoculation with Glomus clarum (CT and the double inoculation S $30+$ BR 11284), PB cassava percentages were reduced.

Through determination of crude protein (CP), it was found that PGPBs contributed to cassava's nitrogen nutrition; plants usually had a higher $\mathrm{CP}$ concentration than the absolute control and were not different from the nitrogen control, suggesting that the inoculated plants settled and assimilated nitrogen in the same proportion to those that received the dose of $71 \mathrm{~kg} \mathrm{~N} \cdot \mathrm{ha}^{-1}$. The study also showed that the strain Herbaspirillum seropedicae was the most efficient in the use of atmospheric $\mathrm{N}$ when compared with the absolute control. The reasons that lead to variation in the BNF response in cassava have not been fully elucidated, suggesting that the interaction between genotype and the environment has a significant influence on the efficiency of diazotrophic organisms (BABALOLA; GLICK, 2012).

Under the studied conditions, it is suggested that $\mathrm{N}$ addition becomes unnecessary, which would explain the great versatility in crop production in low fertility soils. This feature highlights the importance of introducing microorganisms to cassava crops because they play an important role in its establishment and maintenance (BALOTA et al., 1997).

The phosphorus (P) content in the shoot dry matter (PSDM) did not differ significantly at the level of $\mathrm{p}<0.05$ when plants were inoculated with the PGPBs and co-inoculated with G. clarum (Table 8 ). The lack of differences for plants not inoculated with AMF occurred because they do not contain sufficient biomass for match analysis (P) of SDM.

Regarding the accumulation of phosphorus (P) in the SDM, the results of this study corroborate those observed by Balota et al. (1997), who found that PGPBs did not influence the $\mathrm{P}$ accumulation in shoots of micropropagated cassava plants in the presence of $G$. clarum when evaluated at 95 days after planting. The average accumulation of 3.14 $\mathrm{g} \cdot \mathrm{kg}^{-1} \mathrm{P}$ dry matter in this study was close to those analyzed by the same author $\left(2.64 \mathrm{~g} \cdot \mathrm{kg}^{-1}\right.$ dry mass $)$. Likewise, Lima et al. (2011) evaluated the PGPBs and AMF interaction in papaya seedlings and concluded that PGPBs did not influence the $\mathrm{P}$ content in the dry matter of shoots. However, despite this macronutrient being extracted by cassava in lower quantities, it was observed that plants showed restrictions in development in the absence of $G$. clarum, and this can be related to limitations in $\mathrm{P}$ availability. According to Grant et al. (2001), P deficiency symptoms include reduced plant height, a delay in the emergence of leaves and sprouting, and reduced development of secondary roots and dry matter production. 
E. A. P. LOPES et al.

Table 8. Crude protein and accumulated phosphorus content in the dry matter of shoots (PSDM) of micropropagated cassava plants (Manihot esculenta Crantz) cv. (BRA Pretinha III) evaluated at 100 days after planting in relation to inoculation of PGPBs and Glomus clarum.

\begin{tabular}{|c|c|c|c|c|}
\hline \multirow[t]{2}{*}{ Treatments } & \multicolumn{2}{|c|}{$\begin{array}{c}\text { Crude protein } \\
\%\end{array}$} & \multirow{2}{*}{\multicolumn{2}{|c|}{$\begin{array}{c}\text { PSDM } \\
\frac{\mathrm{g} \mathrm{P}^{\mathrm{k}} \mathrm{kg}^{-1} \mathrm{SDM}}{\text { with AMF }}\end{array}$}} \\
\hline & with AMF & non AMF & & \\
\hline S. sp. & 24.88 aA & 25.41 abcA & 3.20 & $\mathrm{a}$ \\
\hline A. amazonense & $23.03 \mathrm{aA}$ & 23.82 abcA & 3.11 & $\mathrm{a}$ \\
\hline H. seropedicae & $24.62 \mathrm{aB}$ & 29.72 & 3.07 & $\mathrm{a}$ \\
\hline G. diazotrophicus & $25.13 \mathrm{aA}$ & $27.41 \quad \mathrm{abcA}$ & 3.15 & a \\
\hline S. sp. + A. amazonense & $22.97 \mathrm{aA}$ & 24.63 & 3.08 & a \\
\hline S. sp. + H. seropedicae & $27.25 \mathrm{aA}$ & $24.29 \mathrm{abcA}$ & 3.10 & a \\
\hline S. sp. + G. diazotrophicus & $27.17 \mathrm{aA}$ & $20.02 \mathrm{cB}$ & 3.18 & $\mathrm{a}$ \\
\hline A. amazonense $+H$. seropedicae & $25.47 \mathrm{aA}$ & 22.91 abcA & 3.12 & $\mathrm{a}$ \\
\hline A. amazonense $+G$. diazotrophicus & $21.18 \mathrm{aA}$ & 23.59 & 3.12 & $\mathrm{a}$ \\
\hline G. diazotrophicus $+H$. seropedicae & $24.01 \mathrm{aA}$ & 22.49 & 3.22 & $\mathrm{a}$ \\
\hline $\mathrm{CN}$ & $26.01 \mathrm{aA}$ & 28.29 abA & 3.17 & $\mathrm{a}$ \\
\hline CT & 26.31 aA & $20.68 \mathrm{bcB}$ & 3.20 & a \\
\hline Means & 24.84 & 24.44 & 3.14 & \\
\hline$\% \mathrm{CV}$ & & & 2.67 & \\
\hline
\end{tabular}

Means followed by the same lowercase letter between treatments within the same column and capital letter between the AMF within the same row for each parameter did not differ by Tukey test $(\mathrm{p}<0.05)$. Azospirillum amazonense (BR 11140), Herbaspirillum seropedicae (BR 11175), Gluconacetobacter diazotrophicus (BR 11284), Streptomyces sp (S 30), nitrogen control (CN) and absolute control (CT). Average of 3 repetitions.

$P$ availability in the soil is an important factor in edaphic intraradicular fungal growth because it affects root exudation; these components may be important for fungal nutrition and in molecular signaling during pre-infection processes and colonization (GARG; CHANDEL, 2010). The benefits promoted by $G$. clarum in cv. "BRA Pretinha III" were demonstrated by the P content in the soil of $16 \mathrm{mg} \cdot \mathrm{dm}^{-3}$, which supports Howeler, Cadavid and Burckhardt (1982) that noted the available $\mathrm{P}$ level required to obtain $95 \%$ of maximum production was approximately $15 \mathrm{mg} \cdot \mathrm{dm}^{-3}$ in mycorrhizal plants, and it was $190 \mathrm{mg} \cdot \mathrm{dm}^{-3}$ in those that were not inoculated. For Balota et al. (1997), the significant increase in cassava dry matter, depending on AMF inoculation, occurred because soil $\mathrm{P}$ contents were at the critical limit for cassava development ( 8 to $10 \mathrm{mg} \cdot \mathrm{dm}^{-3}$ ). The results support investments to enhance this technology and consolidate the use of inoculants in the cassava crop.

The co-inoculation PGPBs and G. clarum can meet the $\mathrm{N}$ need for cassava, implying the reduced use of nitrogen fertilizer, suggesting reduced costs and contributing to more sustainable agriculture.

\section{CONCLUSIONS}

The inoculation with Glomus clarum was sufficient for the best growth of cassava cv. BRA Pretinha III. The co-inoculation with PGPBs did not improve the mycorrhizal colonization relative to the absolute control, thus it is suggested that the simple inoculation with AMF was responsible for the greater growth and accumulation of $\mathrm{N}$ by the cassava seedlings. Overall the crude protein content revealed the contribution of PGPBs in nitrogen nutrition of cassava where the inoculated plants assimilated $\mathrm{N}$ in equal proportion with those that received mineral $\mathrm{N}$.

\section{REFERENCES}

ARAÚJO, W. L. et al. Diversity of endophytic bacterial populations and their interations with Xylella fastidiosa in citrus plants. Applied and Environmental Microbiology, v. 68, n. 10, p. 49064914, 2002.

ARTHURSON, V. et al. Effects on Glomus mosseae root colonization by Paenibacillus polymyxa and Paenibacillus brasilensis strains as related to soil Pavailability in winter wheat. Applied and Environmental Soil Science, v. 2011, n. 1, p. 1-9, 2011.

AZCÓN-AGUILAR, C.; BAREA, J. M. Nutrient cycling in the mycorrhizosphere. Journal of Soil Science and Plant Nutrition, v. 25, n. 2, p. 372396, 2015.

BABALOLA, O. O.; GLICK, B. R. Indigenous African agriculture and plant associated microbes: Current practice and future transgenic prospects. Scientific Research and Essays, v. 7, n. 28, p. 2431 $-2439,2012$.

BALEMI, T.; NEGISHO, K. Management of soil phosphorus and plant adaptation mechanisms to phosphorus stress for sustainable crop production: a 
review. Journal of soil science and plant nutrition, v. 12, n. 3 , p. $547-562,2012$.

BALOTA, E. L. et al. Inoculação de bactérias diazotróficas e fungos micorrízicos-arbusculares na cultura da mandioca. Pesquisa Agropecuária Brasileira, v. 32, n. 6, p. 627-639, 1997.

BOGINO, P. et al. Water-Limiting Conditions Alter the Structure and Biofilm-Forming Ability of Bacterial Multispecies Communities in the Alfalfa Rhizosphere. Plos One, v. 8, n. 11, p. 1-17, 2013.

CARDOSO, E. J. B. N. et al. Micorrizas Arbusculares na aquisição de nutrientes pelas plantas. In: SIQUEIRA, J. O. et al. (Eds.). Micorrizas: 30 anos de pesquisas no Brasil. Lavras: UFLA, 2010. v. 1, cap. 6, p. 153-214.

CHURCHLAND, C.; GRAYSTON, S. J. Specificity of plant-microbe interactions in the tree mycorrhizosphere biome and consequences for soil C cycling. Frontiers in Microbiology, v. 5, n. 261, p. 1-20, 2014.

CORREA, N. de J. C. Comportamento de cultivares de mandioca (Manihot esculenta Crantz) em presenca do fungo micorrizico Glomus clarum Nicolson \& Schenck e dosagens de fosforo. Ciência e Prática, v. 16, n. 4, p. 467-474, 1992.

CUENCA, G.; AZCÓN, R. Effects of ammonium and nitrate on the growth of vesicular-arbuscular mycorrhizal Erythrina poeppigiana OI Cook seedlings. Biology and Fertility of Soils, v. 18, n. 3, p. $249-254,1994$.

EL-SHARKAWY, M. A. Stress-tolerant cassava: The role of integrative ecophysiology-breeding research in crop improvement. Open Journal of Soil Science, v. 2, n. 1, p. 162-186, 2012.

FOOD AND AGRICULTURE ORGANIZATION OF THE UNITED NATIONS - FAO. Agricultural production. Disponível em <http://faostat.fao.org/ site/339/default.aspx.>. Acesso em: 20 mai. 2014.

FERREIRA, D. F. Sisvar: Versão 5.1 (Build 72). DEX/UFLA. 2007.

FREY-KLETT, P.; GARBAYE, J.; TARKKA, M. The mycorrhiza helper bacteria revisited. New Phytologist, v. 176, n. 1, p. 22-36, 2007.

GARG, N; CHANDEL, S. Arbuscular mycorrhizal networks: process and functions. A review. Agronomy for Sustainable Development, v. 30, n. 3, p. 581-599, 2010. mycorrhizal Endogone species extracted from soil by wet-sieving and decanting. Transactions of the British Mycological Society, v. 46, n. 2, p. 235-244, 1963.

GRANT, C. A. et al. A impotância do fósforo no desenvolvimento inicial da planta. Informações Agronômicas, v. 1, n. 95, p. 1-5, 2001.

HASSAN, S.; MATHESIUS, U. The role of flavonoids in root-rhizosphere signalling: opportunities and challenges for improving plantmicrobe interactions. Journal of Experimental Botany, v. 63, n. 9, p. 3429-3444, 2012

HOAGLAND, D. R.; ARNON, D. I. The water culture method for growing plants without soils. Berkeley: California Agricultural Experimental Station. 1950. v. 1, 1-32 p.

HODGE, A.; STORER, K. Arbuscular mycorrhiza and nitrogen: implications for individual plants through to ecosystems. Plant Soil, v. 386, n. 1-2, p. $1-19,2015$.

HOWELER, R. H.; CADAVID, L. F.; BURCKHARDT, E. Response of cassava to VA mycorrhizal inoculation and phosphorus application in greenhouse and field experiments. Plant and Soil, v. 69 , n. 3 , p. $327-339,1982$

JÄDERLUND, L. et al. Specific interactions between arbuscular mycorrhizal fungi and plant growth-promoting bacteria: as revealed by diferent combinations. FEMS Microbiology Letters, v. 287, n. 2 , p. $174-180,2008$

JARSTFER, A.G.; SYLVIA, D.M. Inoculum production and inoculation strategies for vesicular arbuscular mycorrhizal fungi. In: BLAINE MEETING Jr. F. (Ed.). Soil Microbial Ecology. Application in Agricultural and Environmental Management. Marcel Decker, New York, p. 349$369,1992$.

JENKINS, W. R. A rapid centrifugal-flotation technique for separating nematodes from soil. Plant Disease Reporter, v. 48, n. 9, p. 629, 1964

LAREEN, A.; BURTON, F.; SCHÄFER, P. Plant root-microbe communication in shaping root microbiomes. Plant Molecular Biology, v. 90, n. 6, p. $575-587,2016$.

LIMA, K. B. et al. Fungos micorrízicos arbusculares, bactérias diazotróficas e adubação fosfatada em mudas de mamoeiro. Revista Brasileira de Fruticultura, v. 33, n. 3, p. 932-940, 2011. 
LIU, H. X. et al. Biological control of Ralstonia wilt, Phytophthora blight, Meloidogyne root-knot on bell pepper by the combination of Bacillus subtilis AR12, Bacillus subtilis SM21 and Chryseobacterium sp. R89. European Journal of Plant Pathology, v. 139, n. 1, p. $107-116,2014$

LÓPEZ-GARCÍA， A.; AZCÓN-AGUILAR， C.; BAREA, J. M. The interactions between plant life form and fungal traits of arbuscular mycorrhizal fungi determine the symbiotic community. Oecologia, v. 176, n. 4, p. 1075-1086, 2014.

MATTOS, P. L. P.; SOUZA, A. S.; FERREIRA FILHO, J. R. Propagação. In: SOUSA, L. S. et al. (Eds.). Aspectos socioeconômicos e agronômicos da mandioca. Cruz das Almas: Embrapa Mandioca e Fruticultura Tropical. 2006. v. 1, cap. 16, p. 455 491.

MEDINA, A.; AZCÓN, R. Effectiveness of the application of arbuscular mycorrhiza fungi and organic amendments to improve soil quality and plant performance under stress conditions. Journal of Soil Science and Plant Nutrition, v. 10, n. 3, p. 354-372, 2010.

MELLO, M. R. F. et al. Seleção de bactérias e métodos de bacterização para promoção de crescimento em mudas de abacaxizeiro micropropagadas. Summa Phytopathologica, v. 28, n. 3 , p. $222-228,2002$.

MIRANDA, J. C. C. Cerrado: Micorriza arbuscular, ocorrência e manejo. Planaltina, DF: Embrapa Cerrados. 2008. v. 1, 169 p.

MOREIRA, F. M. S.et al. Bactérias fixadoras de nitrogênio e fungos micorrízicos arbusculares em espécies florestais: avanços e aplicações biotecnológicas. In: FIGUEIREDO, M. V. B. et al. (Eds.). Biotecnologia Aplicada à Agricultura. Recife: Embrapa Informação Tecnológica. Instituto Agronômico de Pernambuco. 2010. v. 1 , cap.3, p. 439-478.

MORTIMER, P. E.; PEREZ-FERNANDEZ, M. A.; VALENTINE, A. J. The role of arbuscular mycorrhyzal colonization in the carbon and nutrient economy of the tripartite symbiosis with nodulated Phaseolus vulgaris. Soil Biology and Biochemistry, v. 40, n. 5, p. 1019-1027, 2008.

MURASHIGE, T.; SKOOG, F. A revised medium for rapid growth and bio-assays with tobacco tissue culture. Physiologia Plantarum, v. 15, n. 3, p. 473497, 1962.

NICOLSON, T. H.; SCHENCK, N. C. Endogonaceous mycorrhizal endophytes in Florida.
Mycologia, v. 71, n. 1, p. 178-198, 1979.

OLUKUNLE, O. T. Evaluation of Income and Employment Generation from Cassava Value Chain in the Nigerian Agricultural Sector. Asian Journal of Agriculture and Rural Development, v. 3, n. 3, p. 79-92, 2013.

PANICKER, B. et al. Influence of cytokinin levels on in vitro propagation of shy suckering chrysanthemum "Arka Swarna" and activation of endophytic bacteria. In Vitro Cellular and Developmental Biology - Plant, v. 43, n. 6, p. 614622, 2007.

PHILLIPS, J. M.; HAYMAN, D. S. Improved procedures for clearing roots and staining parasitic and vesicular-arbuscular mycorrhizal fungi for rapid assessment of infection. Transactions of the British Mycological Society, v. 55, n. 1, p. 158-161, 1970.

PLENCHETTE, C.; FORTIN, J. A.; FURLAN, V. Growth of several plant species to mycorrhizae in a soil of moderate P-fertility. Plant and Soil, v. 70, n. 2, p. 199-209, 1983

RAAMAN, N.; PATHARAJAN, S. Integration of arbuscular mycorrhizal fungi with micropropagated plants. In: MUKERJI, K. G. MANOHARACHARY, C. (Eds.). Current Concepts in Botany. I.K. International Publishing House. 2006. v. 1, cap. 17, p. 235-251.

REIS, V. M. Método de inoculação de bactérias diazotróficas em plantas de cana-de-açúcar micropropagadas. In: Comunidade Técnico Embrapa Agrobiologia 65. Seropédica. 2004. 4 p.

REIS, V. M. et al. Interações de fungos micorrízicos com outros microrganismos do solo. In: SIQUEIRA, J. O. et al. (Eds.), Micorrizas: 30 anos de pesquisa no Brasil. Lavras: UFLA. 2010. v. 1 , cap.12 , p. 361-382.

ROCA, W. M. et al. Eliminacion de virus y propagacion de clones en la yuca (Manihot esculenta Crantz). In: ROCA, W. M.; MROGINSKI, L. A. (Eds.). Cultivo de Tejidos en la Agricultura: Fundamentos y Aplicaciones. CIAT. 1991. v. 1, cap. 17, p. $403-420$

RODRIGUES, A. C. et al. Interrelationship of Bradyrhizobium $s p$. and plant growth-promoting bacteria in cowpea: survival and symbiotic performance. Journal of Microbiology, v. 51, n. 1, p. 49-55, 2013

ROESCH, L. F. et al. Reinoculação de bactérias diazotróficas aumentando o crescimento de plantas de trigo. Ciência Rural, v. 35, n. 5, p. 1201-1204, 
2005.

RUÍZ-SÁNCHEZA, M. et al. Azospirillum and arbuscular mycorrhizal colonization enhance rice growth and physiological traits under well- watered and drought conditions. Journal of Plant Physiology, v. 168, n. 10, p. 1031-1037, 2011.

SALA, V. M. R., FREITAS, S. S.; SILVEIRA, A. P. D. Interação de fungos micorrízicos arbusculares e bactérias diazotróficas em trigo. Pesquisa Agropecuária Brasileira, v. 42, n. 11, p. 15931600, 2007.

SILVA, F. C. da. Manual de análises químicas de solos, plantas e fertilizantes. 2. ed. Brasília, DF: Embrapa Informação Tecnológica, 2009. 627 p.

SILVEIRA, J. A. G. et al. Phosphoenolpyruvate carboxylase and glutamine synthetase activities in relation to nitrogen fixation in cowpea nodules. Revista Brasileira de Fisiologia Vegetal, v. 10, n. 1, p. 9-23, 1998.

SOUZA, A. S. et al. Micropropagação da mandioca. In: JUNGHANS, T. G.; SOUZA, A. S. (Eds.). Aspectos práticos da micropropagação de plantas. Cruz das Almas: Embrapa Mandioca e Fruticultura Tropical. 2009. v. 2, cap. 13, p. 323-349.

VARELA-CERVERO, S. Differences in the composition of arbuscular mycorrhizal fungal communities promoted by different propagule forms from a Mediterranean shrubland. Mycorrhiza, v. 26, n. 5, p. 489-496, 2016.

VACHERON, J. et al. Plant growth-promoting rhizobacteria and root system functioning. Frontiers in Plant Science, v. 4, n. 356, p. 1-19, 2013.

WANG, X. et al. Effects of co-inoculation with arbuscular mycorrhizal fungi and rhizobia on soybean growth as related to root architecture and availability of $\mathrm{N}$ and P. Mycorrhiza, v. 21, n. 3, p. 173-181, 2011.

WATANABE, F. S.; OLSEN, S. R. Test of an ascorbic acid method for determining phosphorus in water and $\mathrm{NaHCO}_{3}$ extracts from soil. Soil Science Society of America Proceedings, v. 29, n. 6, p. 677678, 1965. 